RAD Conference Proceedings, vol. 3, pp. 143-148, 2018

ISSN 2466-4626 (online) | DOI: 10.21175/RadProc.2018.31

www.rad-proceedings.org

\title{
HIGH PREVALENCE OF CHRONIC LYMPHOCYTIC LEUKEMIA AND B-CELL LYMPHOMAS IN NUCLEAR WORKERS AFTER THE INCORPORATION OF ALPHA EMITTERS: CASE REPORT AND REVIEW OF THE LITERATURE
}

\author{
Roland Wolff ${ }^{*}$, Rainer Frentzel-Beyme ${ }^{2}$, Inge Schmitz-Feuerhake3
}

${ }^{1}$ Expert for Radiation Protection and Medical Physics Roland Wolff (DGSV), Bremen, Germany ${ }^{2}$ Department of Environmental Research and Technology, University of Bremen (retired), Bremen, Germany

3Department of Physics, University of Bremen (retired), Bremen, Germany

\begin{abstract}
Chronic lymphatic leukemia (CLL) was formerly considered to be a non-radiogenic form of cancer. NonHodgkin Lymphomas (NHL) were supposed to be very rare after radiation exposure. These historical estimations were based on the early observations of the Japanese A-bomb survivors. In contrast to these conclusions, increasing rates of CLL and NHL were found in the last decades in nuclear workers and liquidators of Chernobyl, i.e. in cases of low dose chronic exposure. Estimating the dose response, the authors generally refer to the bone marrow as the corresponding target organ which often leads to surprisingly high-risk figures for the radiation effect. We recently investigated three cases of people suffering from B-lymphocyte proliferation (two CLLs and one lymphoma) who were involved in the decontamination of nuclear establishments, because Germany decided to go out of nuclear energy, and they started tearing down the plants. The men worked in the same enterprise, were exposed to external doses of 46, 108 and $116 \mathrm{mSv}$, and had certainly inhaled alpha emitters such as uranium and plutonium isotopes. In the 1980s, radiation hematologists stated that the bone marrow should not be considered as the relevant target of $B$ cell lymphomas and CLL of B-cell type because the effect results in a proliferation of mature B lymphocytes which mainly occur outside the bone marrow. Therefore, the diseases may be induced in the whole pool of $B$ lymphocytes including all peripheral locations also comprising lymph nodes and lymphatic organs. Our impression is that CLL and NHL are initiated predominantly at workplaces where the possibility of open radioactivity exists: in uranium mines, uranium and radium processing facilities, nuclear facilities, and consequently in liquidators. Several studies involving animals and humans have shown that incorporated radionuclides such as uranium, thorium, and plutonium concentrate in the lymph nodes leading to higher radiation doses to the lymphocytes than are provided in other tissues. This effect is explained by the immunological reaction of macrophages functioning as scavengers of particles such as materials emitting alpha-radiation. These cells circulating via the lymph vessels are stored in the stationary lymph nodes. If the target organ for dosimetry must be seen in all mature B lymphocytes in the body, this will be valid for all kinds of external and internal exposures. Except in cases of homogeneous whole-body exposure, any dose estimation will be extremely unsafe or - as in our examples - not possible. These limitations must be considered when planning the radiation protection strategies for nuclear workers and adequate evaluation in compensation cases.
\end{abstract}

Key words: Radiation-induced lymphomas, chronic low-dose exposure, target organ, lymph nodes, accumulation of radionuclides

\section{INTRODUCTION}

Based on statistics, former experts claimed that Non-Hodgkin Lymphomas (NHL) could be expected $a$ ) only after high doses as in the exposed cohorts of the Japanese A-bomb survivors, b) in cases of radiation therapy, or $c$ ) in patients exposed to thorium dioxide used as a contrast medium [1]. First systematic registration of NHL in workers began when the US Public Health Service initiated a program in 1950 in order to control the health effects occurring in the uranium industry. Archer et al. [2] studied cancer mortality among uranium mill workers and detected remarkable numbers of excess deaths due to malignant diseases of the lymphatic and hematopoietic tissue other than leukemia, predominantly lymphomas. They explained these results by applying the findings of the previous experiments dealing with the accumulation of uranium and thorium in the tracheobronchial lymph nodes of animals.

Reports about NHL in occupationally exposed persons became more frequent in the last decades and often led to surprisingly high relative risk estimates among cohorts of so-called "liquidators". These survivors were about 800,000 men who were deployed by the Soviet Union for shielding and decontamination tasks after the explosion of the Chernobyl reactor in 1986.

Chronic lymphocytic leukemia (CLL) was formerly considered as non-radiogenic, based on a lack of scientific evidence involving the Japanese A-bomb

*rwstrahlen@online.de 
R. Wolff et al., Chronic lymphocytic leukemia and B-cell lymphomas, RAD Conf. Proc., vol. 3, 2018, 143-148

survivors. This dogma was criticized by Richardson et al. [3]. Since then, CLLs were classified as a subgroup of NHL and characterized as an indolent (low-grade malignant) type of NHL [4].

\section{OBSERVATIONS IN GERMANY}

We recently came upon three cases of people suffering from B-lymphocyte proliferation (2 CLLs and one B-Cell lymphoma) who were involved in the decontamination of closed nuclear establishments, because Germany decided to stop using nuclear energy. The men had worked in several nuclear enterprises, and also in the same former facility producing nuclear fuel rods including mixed oxide fuel assemblies (MOX) containing enriched uranium and plutonium (see Table 1).

Table 1. CLL and NHL in workers after the decontamination of a MOX facility

\begin{tabular}{|c|c|c|c|c|c|c|c|c|}
\hline \multirow[b]{2}{*}{ Patient } & \multirow{2}{*}{$\begin{array}{l}\text { Period of } \\
\text { occupational } \\
\text { exposure }\end{array}$} & \multirow[b]{2}{*}{$\begin{array}{l}\text { Diagnosis } \\
\text { at age }\end{array}$} & \multirow[b]{2}{*}{$\begin{array}{l}\text { Working } \\
\text { with MOX }\end{array}$} & \multicolumn{5}{|c|}{ Applied monitoring } \\
\hline & & & & $\begin{array}{l}\text { External } \\
\text { dose }\end{array}$ & Neutrons & $\begin{array}{l}\text { Beta } \\
\text { extern }\end{array}$ & $\begin{array}{l}\text { Uranium } \\
\text { incorp. }\end{array}$ & $\begin{array}{l}\text { Plutonium } \\
\text { incorp. }\end{array}$ \\
\hline G.H. & 1989-2012 & $46 \mathrm{y}$. & 2001-2006 & $116 \mathrm{mSv}$ & $\begin{array}{l}\text { no } \\
\text { control }\end{array}$ & $\begin{array}{l}\text { not } \\
\text { proved }\end{array}$ & proved & no control \\
\hline J.S. & $1996-2013$ & $49 \mathrm{y}$. & 1996-2000 & $108 \mathrm{mSv}$ & proved & proved & not found & $\begin{array}{l}\text { proved } \\
8.18 .1999\end{array}$ \\
\hline H.T. & 2002-2005 & $52 \mathrm{y}$. & 2002-2005 & $46 \mathrm{mSv}$ & proved & $\begin{array}{l}\text { not } \\
\text { proved }\end{array}$ & proved & no control \\
\hline
\end{tabular}

According to their monitoring data, they were exposed to accumulated external radiation doses of 116, 108 , and $46 \mathrm{mSv}$. Every dose contribution by incorporated radionuclides was estimated to be very low by the Employers Liability Insurance Association (Berufsgenossenschaft), because the persons had gone to court individually.

Between 1996 and 2006, the 3 clients, who required a medical expert opinion, were found to have been allocated by the same employer to the same former facility for fuel assemblies. The employer documented that the places for decontamination contained MOX fuel. This must have been in order to point to the special risks of plutonium, because of its specific activity which is much higher than of uranium (Table 2) and has much higher dose factors in $\mathrm{Sv} / \mathrm{Bq}$ after inhalation.

Table 2. Specific activity of uranium and plutonium

\begin{tabular}{|c|c|}
\hline $1 \mathrm{mg} \mathrm{U}-238$ & $12.4 \mathrm{~Bq}$ \\
\hline $1 \mathrm{mg} \mathrm{Pu}-239$ & $2300000 \mathrm{~Bq}$ \\
\hline
\end{tabular}

The content of $\mathrm{Pu}$ in MOX fuels, which were used in German nuclear power plants, was up to $5 \%$ of the mass. It could, however, amount to up to $30 \%$ for other configurations [5]. The applied methods for personal monitoring, which are listed in Table 1, were not standardized and were not complete for these conditions. In two cases, a neutron dose was registered. This confirms the occurrence of plutonium in the workplaces, because the spontaneous fission rate of $\mathrm{Pu}$ is much higher than that of enriched U. Therefore, a measurable dose-rate by neutrons cannot be originated by pure uranium fuel [5].

In one case of incorporated uranium measured in a whole-body counter (G.H.), the technical service of the assurance derived a lung dose of $0.079 \mathrm{mSv}$ by inhaled uranium. Assuming there was contaminating Pu in the fuel mixture, then the lung dose could have grown up to some Sv.
The similarity of the specific diagnoses which are normally very rare in ages below 52 provides evidence that they are caused by a relevant dose contribution due to the inhalation of alpha emitters.

\section{EPIDEMIOLOGICAL FINDINGS ABOUT NON-HodGKIN LYMPHOMAS IN A-BOMB SURVIVORS AND OCCUPATIONALLY EXPOSED WORKERS}

A compilation of references about the reported Non-Hodgkin Lymphomas and occupation in Tables 3 and 4 concerns only male employees. For historical reasons, "lymphomas" and "chronic lymphocytic leukemia" are considered separately. The results may also differ because of different coding chosen by the authors, because the classification of these diseases changed considerably in the last decades [6].

In obtaining risk figures for radiation induction, another principal problem is the fact that indolent lymphomas have a fair prognosis after therapy and will not generally appear in mortality studies.

Significant excess of NHL in the Japanese A-bomb survivors was not reported before 1994, and it was observed only in men [7]. This may be due to the fact that these diseases were extremely rare in the Japanese population, and that the latency periods after exposure are normally very long [3], [8]. The update of the incidence in 2013 (No. 1 in Table 3) leads to a similar result. This is in contrast with a former analysis of Richardson et al. [8] who used the same database. They investigated the mortality of men above the age of 15 who were exposed to the dose range below $500 \mathrm{mSv}$ and observed the fact that the deaths occurred predominantly more than 35 years after exposure. Their lowest result about a doubling dose of $236 \mathrm{mSv}$ was obtained assuming a 10-year lag between the exposure and death (No. 1 in Table 3).

No. 2 in Table 3 represents the mentioned historical work of Archer et al. [2].

The studies involving U.S. nuclear workers (No. 3-4 in Table 3) show surprisingly high risks. The authors of 
R. Wolff et al., Chronic lymphocytic leukemia and B-cell lymphomas, RAD Conf. Proc., vol. 3, 2018, 143-148

study No. 3 investigated a group of men with registered external exposure assuming no internal contribution, and another group with predominant internal exposure to uranium, fission products and "small amounts of plutonium" [10]. Study No. 4 belongs to the already mentioned investigation of 2009 in the Japanese survivors and was done for comparison with these [8]. The doubling dose of $131 \mathrm{mSv}$ was derived again by assuming a 10 year-lag without effect.

No. 5 (Table 3) reports data about workers in the nuclear complex of Mayak (Southern Urals). Two facilities were considered: a nuclear reactor and a reprocessing plant for plutonium extraction [11]. The workers were divided into those who started working there before 1954 and after this point. In every subgroup, excess rates of NHL compared to the Russian population were confirmed. The highest relative risk of 3.5 appeared in the reprocessing cohort with those starting before 1954 .

The study of the British reprocessing plant Sellafield (No. 6 in Table 3) combined lymphomas and multiple myelomas, and found the highest relative risk of 3.8 assuming a 20-year lag [12]. The estimated mean effective dose of $164 \mathrm{mSv}$ is gained assuming the highest solubility class for inhaled Pu. The incidence of NHL was 2-fold higher in workers exposed to incorporated $\mathrm{Pu}$ in comparison to other radiation workers.
The analysis involving nuclear shipyard workers (No. 7) also considers lymphomas together with multiple myelomas [13]. The highest noted relative risk of 5.8 is reached assuming a 10-year lag in the dose range above $10 \mathrm{mSv}$.

The study involving liquidators (No. 8) refers to a combined collective of men from Belarus, Russia and Baltic countries [14]. The estimated dose is derived for the red bone marrow which may be the reason for the resulting high-risk figure.

Excess deaths of radiologists suffering from NHL (No. 9) may be explained by high doses at the early stages of X-ray and radium applications [15].

The high prevalence in flight personnel (No. 10) is surprising considering the rather low official estimates of their exposure and the short follow-up [16].

The last cited study in Table 3 was listed here because it clearly shows that the bone marrow cannot serve as the critical organ for radiation-induced NHL. The data are derived from 12 incident NHLs which appeared in 3.440 patients suffering from nasopharyngeal cancer after radiotherapy with radium [17]. Because of the limited radiation field, the mean bone marrow dose was estimated to only $5 \mathrm{mSv}$. This leads to an ERR Sv $\mathrm{Sv}^{-1}$ of 280 and a doubling dose for the effect of $4 \mathrm{mSv}$ which may not appear acceptable as a reliable result.

Table 3. Epidemiological studies on radiation-induced Non-Hodgkin Lymphomas in men (RR - relative Risk, n.e. - not estimated, n.s. - not significant)

\begin{tabular}{|c|c|c|c|c|c|c|c|c|c|}
\hline No. & Collective & $\begin{array}{l}\text { Number of } \\
\text { exposed } \\
\text { persons }\end{array}$ & $\begin{array}{l}\text { Mean } \\
\text { Follow-up } \\
\text { y. }\end{array}$ & & exp. & $\mathrm{RR}$ & $\begin{array}{l}\text { Dose Sv } \\
\text { Mean } \\
\text { or range }\end{array}$ & $\begin{array}{l}\text { Doubling } \\
\text { Dose Sv }\end{array}$ & Remarks \\
\hline & \multicolumn{9}{|c|}{ Japanese A-bomb survivors } \\
\hline \multirow[t]{2}{*}{$\mathbf{1}$} & $\begin{array}{l}\text { Analysis } 2013[9] \\
\text { Analysis 2009 [8] }\end{array}$ & $\begin{array}{l}45,000 \\
20,940\end{array}$ & 31.9 & 73 & & & $\begin{array}{l}0.2 \\
<0.5\end{array}$ & $\begin{array}{l}2.2 \\
0.236^{* * *}\end{array}$ & $\begin{array}{l}\text { Incidence } \\
\text { Mortality }\end{array}$ \\
\hline & \multicolumn{9}{|c|}{ Occupationally exposed persons } \\
\hline 2 & $\begin{array}{l}\text { Uranium mills } \\
\text { USA [2] }\end{array}$ & 715 & $2-13$ & 4 & 1.02 & 3.9 & n.e. & & Mortality \\
\hline 3 & $\begin{array}{l}\text { Nuclear technique, } \\
\text { weapons Atomics } \\
\text { Int. + Rocketdyne } \\
\text { USA 1955-93[10] }\end{array}$ & $\begin{array}{l}4,563 \\
2,207\end{array}$ & & $\begin{array}{r}28 \\
8\end{array}$ & & $\begin{array}{l}15 \cdot 7 \\
44.6\end{array}$ & $\begin{array}{l}\geq 0.2 \\
\geq 0.03\end{array}$ & & $\begin{array}{l}\text { External exposure } \\
\text { Internal exposure } \\
\text { Mortality } \\
\text { ICD 200-208 }\end{array}$ \\
\hline 4 & $\begin{array}{l}\text { Atomic weapons } \\
\text { Savannah River } \\
\text { 1950-2002 [8] }\end{array}$ & 15,267 & & 51 & & & & $0.131^{* *}$ & Mortality \\
\hline 5 & $\begin{array}{l}\text { Mayak workers [11] } \\
\text { USSR 1958-1986 }\end{array}$ & 1812 & 34 & 25 & 7.11 & $3 \cdot 5^{* *}$ & $0.02-0.7$ & & $\begin{array}{l}\text { Mortality } \\
\text { ICD 200-208 }\end{array}$ \\
\hline 6 & $\begin{array}{l}\text { Sellafield reproc. } \\
\text { U.K. 1971-1986 [12] }\end{array}$ & 11,635 & 28.6 & 15 & & $3.8^{* *}$ & 0.164 & 0.059 & $\begin{array}{l}\text { Incidence } \\
\text { ICD 200-209 } \\
\end{array}$ \\
\hline 7 & $\begin{array}{l}\text { U.S. nuclear ship- } \\
\text { yard workers [13] }\end{array}$ & 30,462 & 12.8 & 50 & & $5.8^{* *}$ & & & $\begin{array}{l}\text { Incidence } \\
\geq 10 \mathrm{mSv}\end{array}$ \\
\hline 8 & $\begin{array}{l}\text { Liquidators Cher- } \\
\text { nobyl USSR [14] }\end{array}$ & 146,000 & & 20 & & & $\begin{array}{l}\text { Median } \\
\text { o.013 }\end{array}$ & $0.036^{*}$ & $\begin{array}{l}\text { Incidence } \\
\text { Case-control study }\end{array}$ \\
\hline 9 & $\begin{array}{l}\text { Radiologists U.K. } \\
\text { 1897-19979 [15] }\end{array}$ & 2,698 & 25.8 & 9 & 2.9 & 3.1 & n.e. & & Mortality \\
\hline 10 & $\begin{array}{l}\text { Metaanalysis flight } \\
\text { attendants [16] }\end{array}$ & 10,551 & $<19.3$ & 6 & & 2.5 & n.e. & & Incidence \\
\hline 11 & $\begin{array}{l}\text { Radium-therapy } \\
\text { Nasopharynx [17] }\end{array}$ & 3,440 & 31 & 12 & 5 & 2.4 & $0.005^{*}$ & $0.004^{*}$ & Incidence \\
\hline
\end{tabular}


R. Wolff et al., Chronic lymphocytic leukemia and B-cell lymphomas, RAD Conf. Proc., vol. 3, 2018, 143-148

The former dogma categorizing CLL as a nonradiogenic disease ignored the fact that the Japanese study of the cohort "Not in city" had shown an excess of CLL (see No. 1 in Table 4). These people had not been in the cities at time of the bombing and were not exposed to direct radiation during the explosion [18]. They came some days later in order to search for their relatives or to help the victims. They were formerly assumed to be a suitable control population. They were, however, exposed to the fallout of the bombs, which deposited predominantly outside the cities, and the residual radiation produced by neutron activation near the hypocenters. Later studies of the effects of the fallout and other residual exposures showed remar

kable cancer risks [19]. Excess cases of CLL in the "Life Span Study", which is the usual reference and is related to the direct penetrating radiations by gamma rays and neutrons - without residual contribution were not registered before 2001 (Table 4).

The study in nuclear workers (No. 2) involved the personnel of 4 weapons facilities and one nuclear naval shipyard [20]. It predicts high relative radiation risks of CLL in workers when long periods of follow-up are considered.

CLL was identified to be the most frequent form of leukemia in the liquidators of Chernobyl [21]. Corresponding studies cited in Table 4 (No. 3) result in rather high risk figures per dose, the effects are related to the bone marrow dose - the applied method in most of these investigations. The study by Bazyka et al. [22] is a Ukrainian continuation of the former UkrainianAmerican project on liquidators which was a casecontrol study. It showed a significant increase of CLL analyzing cases until 2006 [23], the resulting ERR/Gy is given in the table.

Table 4. Epidemiological studies on radiation-induced Chronic Lymphocytic Leukemia (RR - Relative Risk, ERR - Excess Relative Risk, ERR=1-RR)

\begin{tabular}{|c|c|c|}
\hline No. & Exposed Collective and Reference & Description and Results \\
\hline 1 & $\begin{array}{l}\text { Japanese A-bomb survivors } \\
\text { Hiroshima/Nagasaki “Not in City" [18] } \\
\text { Hiroshima/Nagasaki Life Span Study until } 2001 \\
\text { [9] }\end{array}$ & $\begin{array}{l}\text { Number of persons } 26,508 \\
\text { Observed/Expected Cases } 28 / 19 \quad \mathrm{RR}=1.5 \\
\text { CLL cases } 12 \\
\text { significant increase per dose }\end{array}$ \\
\hline 2 & $\begin{array}{l}\text { Nuclear workers } \\
5 \text { Nuclear facilities USA [20] }\end{array}$ & $\begin{array}{l}\text { Exposed men 94,5000 } \text { Case-control study } \\
\text { CLL deaths } 43 \quad \text { ERR }=20 \mathrm{~Sv}^{-1}<100 \mathrm{mSv} \text { n.s. }\end{array}$ \\
\hline 3 & $\begin{array}{l}\text { Liquidators of Chernobyl } \\
\text { In Belarus, Russia, Baltic states [14] } \\
\text { In Ukraine 1987-2012 [22] }\end{array}$ & $\begin{array}{l}\text { Exposed persons } 146,000 \text {, Case-control study, Incidence } \\
\text { Cases } 21 \mathrm{ERR}=4.7 \mathrm{~Gy}^{-1} \text { Median dose } 13 \mathrm{mGy} \\
\\
\text { Exposed persons } 152,520 \text {, Incidence study, Observed cases } 146 \\
\text { ERR }=2.6 \mathrm{~Gy}^{-1 *} \text { in the period until } 2006\end{array}$ \\
\hline 4 & Uranium miners Czech Republic [23] & $\begin{array}{l}\text { Exposed persons } 23,043, \text { Incidence } \\
\text { Observed/Expected cases } 42 / 21.2 \quad \mathrm{RR}=\mathbf{2 . 0}\end{array}$ \\
\hline 5 & Uranium miners Germany [24] & $\begin{array}{l}\text { Exposed persons } 360,000 \text {, Case-control study, Incidence } \\
\text { Cases } 377 \mathrm{RR}=2.0 \mathrm{~Gy}^{-1 *} \text { mean dose } 24.6 \mathrm{mGy}\end{array}$ \\
\hline 6 & $\begin{array}{l}\text { Uranium mines/Uranium \& radium refining } \\
\text { and processing USA } \\
1932-1980[25]\end{array}$ & $\begin{array}{l}\text { Exposed persons } 16,770 \text {, Incidence } \\
\text { Mean follow-up } 22 \mathrm{y} \text {. } \\
\text { Cases } 22 \mathrm{ERR}=7.3 \mathrm{~Sv}^{-1 *}\end{array}$ \\
\hline
\end{tabular}

The exposure of uranium miners as well as workers in uranium and radium processing facilities (No. 4-6) to radon and uranium/radium dust probably cannot be quantified because of its complexity.

\section{DOSIMETRY}

CLL and B-cell lymphomas are classified as "Mature B-cell neoplasms" [4]. The proliferation is thought to start at a single transformed cell [27]. In undifferentiated stage, the stem cells of the B lymphocytes are located in the bone marrow. Because the B-cell proliferation occurs in differentiated cells it must be assumed that the primary cell is also differentiated (mature). Mature B lymphocytes are distributed in the circulatory system and concentrate in the lymphatic organs, primarily the lymph nodes.

Radiation-induced B-cell lymphomas - such as a stochastic effect - are also assumed to be induced by a 146 single cell transformation where the target must then be a mature cell [21], [28]-[30]. Therefore, the critical organ for this disease cannot be the bone marrow alone but the whole pool of mature B lymphocytes in the body are targets of radiation.

The ICRP developed a revised human tract model published in 1994, to be able to derive dose factors for the organs and tissues after the inhalation of radionuclides [31]. The description of this compartment model with many metabolic parameters is laid down on 482 pages. The organ doses are given in $\mathrm{Sv}$ per $\mathrm{Bq}$, where the amount in $\mathrm{Bq}$ is the inhaled activity of the regarded nuclide. These dose factors are listed without confidence limits. The critics doubted that the high grade of differentiation compared to the former approaches led to more precise estimations in individual cases.

Roy investigated confidence ranges of the dose factors [32]. For plutonium inhalation, he came to the conclusion that the effective dose may vary within the 
R. Wolff et al., Chronic lymphocytic leukemia and B-cell lymphomas, RAD Conf. Proc., vol. 3, 2018, 143-148

range where the highest value is about 16 -fold greater than the lowest one (90\% confidence).

A further problem, however, is observed in the fact that $\mathrm{Pu}$ and other heavy nuclides as U-, Th- and Raisotopes are accumulated in the lymph nodes where they lead to a much higher exposure to the lymphocytes than in other tissues. This effect is explained by the immunological reaction of macrophages functioning as scavengers of particles such as materials emitting alpha-radiation. These cells moving in the lymph vessels are stored in the stationary lymph nodes. The lung model of the ICRP does not consider this possibility.

The accumulation in the lymph nodes was not only observed in studies involving rodents but also in several investigations involving humans. Kathren et al. made autopsy studies of the lungs and associated lymph nodes of 58 tissue donors [33]. These had been included in the U.S. Transuranium and Uranium Registry (USTUR) which was installed in 1968. They measured the concentration of $\mathrm{Pu}$-isotopes and Americium-241 in these tissues and compared them to the concentration in the general population. The assumed way of ingestion was via inhalation. The mean value for the ratio of $\mathrm{Pu}$ concentration in the lymph nodes to the concentration in the lungs was $7.8 \pm 6.2$. The individual ratios varied between 1 and 427 .

Several autopsy studies of thorium and uranium metabolism confirm the accumulation of radionuclides in human lymph nodes [34]-[37].

\section{CONCLUSION}

In cases of inhomogenous exposure and especially in cases of the incorporation of radioactivity any dose estimation for NHL will become difficult or impossible.

The review of data derived from low-dose exposures and our own experience leads to the conclusion that NHL must be expected predominantly at workplaces where the inhalation of alpha emitting nuclides is not avoidable: in uranium mines and processing of nuclear fuel materials, in nuclear facilities and nowadays at places where such facilities are demolished. The enhancing effect by the accumulation of nuclides in the lymph nodes leads to an exposure of the lymphocytes which is not measurable from the outside, and thus the dose of the critical organ will probably always be underestimated. Radiation-induced NHL should, therefore, be considered as a special problem in the effective protection of radiation workers and in an adequate assessment in compensation cases.

\section{REFERENCES}

1. Sources and effects of ionizing radiation, UNSCEAR 1994 Report to the General Assembly, with scientific Annexes, UNSCEAR, New York (NY), USA, 1994. Retrieved from: http://www.unscear.org/docs/publicat ions/1994/UNSCEAR 1994 Report.pdf; Retrieved on: Aug. 2, 2018

2. V. E. Archer, J. K. Wagoner, F. E. Lundin, "Cancer mortality among uranium mill workers," $J$. Occup. Med., vol. 15, pp. 11 - 14, 1973.

PMid: 4684721
3. D. B. Richardson, S. Wing, J. Schroeder, I. SchmitzFeuerhake, W. Hoffmann, "Ionizing radiation and chronic lymphocytic leukemia." Environ. Health Perspect, vol. 113, no. 1, pp. 1 - 5, Jan. 2005.

DOI: 10.1289/ehp.7433

PMid: 15626639

PMCid: PMC1253701

4. WHO Classification of Tumours of Haematopoietic and Lymphoid Tissues, WHO, Lyon, France, 2008.

Retrieved from: http://publications.iarc.fr/_publicatio ns/media/download/1511/700ac655d7f248cf1044efd98 5275086ed4f341f.pdf;

Retrieved on: Aug. 2, 2018

5. I. R. Terry, "Modern new nuclear fuel characteristics and radiation protection aspects," Radiat. Prot. Dosim., vol. 115, no. 1-4, pp. 110 - 111, 2005.

DOI: $10.1093 / \mathrm{rpd} / \mathrm{nci} 239$

PMid: 16381693

6. K. H. Adzersen, S. Friedrichs, N. Becker, "Are epidemiological data on lymphoma incidence comparable? Results from an application of the coding recommendations of WHO, InterLymph, ENCR and SEER to a cancer registry dataset," J. Cancer Res. Clin. Oncol., vol. 142, no. 1, pp. 167 - 175, Jan. 2016.

DOI: $10.1007 /$ soo432-015-2017-Z PMid: 26206482

7. D. L. Preston et al., "Cancer incidence in atomic bomb survivors. Part III: Leukemia, lymphoma and multiple myeloma, 1950-1987," Radiat. Res., vol. 137, no. 2, pp. S68 - S97, Feb. 1994

DOI: $10.2307 / 3578893$

PMid: 8127953

8. D. B. Richardson et al., "Positive associations between ionizing radiation and lymphoma mortality among men," Am. J. Epidemiol., vol. 169, no. 8, pp. 969 - 976, Apr. 2009.

DOI: $10.1093 / \mathrm{aje} / \mathrm{kwpo18}$

PMid: 19270049

PMCid: PMC2732978

9. W. L. Hsu et al., "The incidence of leukemia, lymphoma, and multiple myeloma among atomic bomb survivors: 1950-2001," Radiat. Res., vol. 179, no. 3, pp. $361-382$, Mar. 2013

DOI: $10.1667 /$ RR2892.1

PMid: 23398354

PMCid: PMC 3875218

10. H. Morgenstern, B. Ritz, "Effects of radiation and chemical exposures on cancer mortality among Rocketdyne workers: a review of three cohort studies," Occup. Med. State Art, vol. 16, no. 2, pp. 219 - 237, Apr-Jun. 2001. PMid: 11319049

11. N. A. Koshurnikova et al., "Mortality from malignancies of the hematopoietic and lymphatic tissues among personnel of the first nuclear plant in the USSR," Sci. Total Environ., vol. 142, no. 1-2, pp. 19 - 23, Mar. 1994. DOI: 10.1016/0048-9697(94)90068-X

12. R. Z. Omar, J. A. Barber, P. G. Smith, "Cancer mortality and morbidity among plutonium workers at the Sellafield plant of British nuclear fuels," Brit. J. Cancer, vol. 79, no. 7-8, pp. 1288 - 1301, Mar. 1999.

DOI: $10.1038 /$ sj.bjc.6690207

PMid: 10098774 PMCid: PMC2362215

13. G. M. Matanoski et al., "Cancer risks and low-level radiation in U.S. shipyard workers," J. Radiat. Res., vol. 49, no. 1, pp. 83 - 91, Jan. 2008 DOI: $10.1269 /$ jrr.06082

14. A. Kesminiene et al., "Risk of hematological malignancies among Chernobyl Liquidators." Radiat. Res., vol. 170, no. 6, pp. 721 - 735, Dec. 2008.

DOI: $10.1667 / R R 1231.1$

PMid: 19138033 
R. Wolff et al., Chronic lymphocytic leukemia and B-cell lymphomas, RAD Conf. Proc., vol. 3, 2018, 143-148

PMCid: PMC2904977

15. A. Berrington, S. C. Darby, H. A. Weiss, R. Doll, "100 years of observation on British radiologists: mortality from cancer and other causes," Brit. J. Radiol., vol. 74, no. 882, pp. 507 - 519, Jun. 2001. DOI: $10.1259 /$ bjr.74.882.740507 PMid: 11459730

16. A. Buja et al., "Cancer incidence among military and civil pilots and flight attendants: an analysis on published data," Toxicol. Ind. Health, vol. 21, no. 10, pp. $273-282$, Nov. 2005.

DOI: $10.1191 / 0748233705^{\text {th }} 238$ oa PMid: 16463960

17. C. M. Ronckers et al., "Cancer incidence after nasopharyngeal radium irradiation," Epidemiology, vol. 13 , no. 5 , pp. $552-560$, Sep. 2002.

DOI: 10.1097/00001648-200209000-00011 PMid: 12192225

18. M. Ichimaru, T. Ishimaru, J. L. Belsky, "Incidence of leukemia in atomic bomb survivors, Hiroshima \& Nagasaki 1950-71," J. Radiat. Res., vol. 19, no. 3, pp. $262-282$, Sep. 1976.

DOI: $10.1269 /$ jrr.19.262 PMid: 739446

19. T. Watanabe, M. Miyao, R. Honda, Y. Yamada, "Hiroshima survivors exposed to very low doses of A-bomb primary radiation showed a high risk for cancers," Environ. Health Prev. Med., vol. 13, no. 5, pp. 264 - 270, Sep. 2008.

DOI: $10.1007 / \mathrm{s} 12199-008-0039-8$

PMid: 19568913

PMCid: PMC2698250

20. M. K. Schubauer-Berigan et al., "Chronic lymphocytic leukaemia and radiation: findings among workers at five US nuclear facilities and a review of the recent literature," Br. J. Haematol., vol. 139, no. 5, pp. $799-808$, Dec. 2007.

DOI: $10.1111 /$ j.1365-2141.2007.06843.x PMid: 17922878

21. D. Gluzman et al., "Patterns of hematological malignancies in Chernobyl clean-up workers (1996-2005)," Exp. Oncol., vol. 28, no. 1, pp. 6o - 63, Mar. 2006. PMid: 16614710

22. D. Bazuka et al., "Chronic lymphocytic leukemia in Chornobyl cleanup workers," Health Phys., vol. 111, no. 2, pp. 186 - 191, Aug. 2016.

DOI: 10.1097/HP.0000000000000440 PMid: 27356063

23. L. B. Zablotska et al., "Radiation and the risk of chronic lymphocytic and other leukemias among Chernobyl cleanup workers," Environ. Health Persp., vol. 121, no. 1, pp. 59-65, Jan. 2013

DOI: $10.1289 /$ ehp.1204996

PMid: 23149165 PMCid: PMC3553431

24. V. Rericha, M. Kulich, R. Rericha, D. L. Shore, D. P. Sandler, "Incidence of leukemia, lymphoma, and multiple myeloma in Czech uranium miners: a casecohort study," Environ. Health Persp., vol. 114, no. 6, pp. $818-822$, Jun. 2006.

DOI: $10.1289 /$ ehp. 8476

PMid: 16759978 PMCid: PMC1480508

25. M. Mohner, J. Gellissen, J. W. Marsh, D. Gregoratto, "Occupational and diagnostic exposure to ionizing radiation and leukemia risk among German uranium miners," Health Phys., vol. 99, no. 3, pp. 314 - 321, Sep. 2010.
DOI: 10.1097/HP.obo13e3181cd6536

PMid: 20699692

26. R. S. Lane, S. E. Frost, G. R. Howe, L. B. Zablotska, "Mor-tality (1950-1999) and cancer incidence (19691999 ) in the cohort of Eldorado uranium workers," Radiat. Res., vol. 174, no. 6a, pp. 773 - 786, Dec. 2010. DOI: $10.1667 / R R 2237.1$ PMid: 21128801

27. Klinische Haematologie, H. Begemann, J. Rastetter, Eds., Stuttgart, Deutschland: Georg Thieme, 1986. (Clinical Hematology, H. Begemann, J. Rastetter, Eds. Stuttgart, Germany: Georg Thieme, 1986.)

28. D. F. Gluzman, L. M. Sklyarenko, V. A. Nadgornaya, M. P. Zavelich, "Mature B-cell neoplasms in Chernobyl clean-up workers of 1986-1987: summary of cytomorpho-logical and immunocytochemical study in 25 years after Chernobyl accident," Exp. Oncol., vol. 33 no. 1, pp. 47 - 51, Mar. 2011. PMid: 21423095

29. M. S. Linet et al., "Chronic lymphocytic leukaemia: an overview of aetiology in light of recent developments in classification and pathogenesis," Br. J. Haematol., vol. 139, no. 5, pp. $672-686$, Dec. 2007. DOI: $10.1111 / \mathrm{j} .1365-2141.2007 .06847 \cdot \mathrm{X}$ PMid: 18021081

30. I. Abramenko et al., "Chronic lymphocytic leukemia patients exposed to ionizing radiation due to Chernobyl NPP accident - with focus on immunoglobulin heavy chain gene analysis," Leukemia Res., vol. 32, no. 4 pp. 535 - 545, Apr. 2008.

DOI: 10.1016/j.leukres.2007.08.013

PMid: 17897714

31. Human Respiratory Tract Model for Radiological Protection, ICRP Publication 66, ICRP, Ottawa, Canada, 1994.

32. M. A. Roy, "Reliability of dose coefficients calculated with the respiratory tract model of the ICRP," Radiat. Prot. Dosim., vol. 79, no. 1-4, pp. 237 - 240, Oct. 1998. DOI: 10.1093/oxfordjournals.rpd.a032400

33. R. L. Kathren et al., "Distribution of Plutonium and Americium in human lungs and lymph nodes and relationship to smoking status," Radiat. Prot. Dosim., vol. 48, no. 4, pp. 307 - 315, Aug. 1993. DOI: 10.1093/oxfordjournals.rpd.ao81878

34. A. S. Goldin, P. J. Magno, F. Geiger, M. L. Janower, "Radionuclides in autopsy samples from thorotrast patients," Health Phys., vol. 22, no. 5, pp. $471-482$, May 1972.

DOI: 10.1097/00004032-197205000-00006 PMid: 5024730

35. L. F. Mausner, "Inhalation exposures at a thorium refinery," Health Phys., vol. 42, no. 2, pp. $231-236$, Feb. 1982. PMid: 7068387

36. A. T. Keane, A. P. Polednak, "Retention of uranium in the chest: implications of findings in vivo and postmortem," Health Phys., vol. 44, suppl. 1, pp. 391 - 402, Jan. 1983.

DOI: 10.1097/00004032-198306001-00037 PMid: 6862916

37. N. P. Singh, D. D. Bennett, M. E. Wrenn, G. Saccomanno, "Concentrations of $\alpha$-emitting isotopes of $\mathrm{U}$ and Th in uranium miners' and millers' tissues," Health Phys., vol. 53, no. 3, pp. 261 - 265, Sep. 1987.

DOI: 10.1097/00004032-198709000-00005 PMid: 3623915 